\title{
Anticellulite efficacy of Trichilia catigua and Ptychopetalum olacoides Bentham extracts
}

\author{
Eficácia anticelulite de extratos de Trichilia catigua e Ptychopetalum olacoides Bentham
}

\author{
Maria Valéria Robles Velasco ${ }^{1 *}$, Idalina Maria Nunes Salgado Reis dos Santos ${ }^{2}$, Michelli Ferrera Dario ${ }^{1}$, \\ Thamires Batello Freire ${ }^{1}$, André Rolim Baby ${ }^{1}$ \\ ${ }^{1}$ Department of Pharmacy, School of Pharmaceutical Sciences, University of São Paulo, São Paulo, Brazil \\ ${ }^{2}$ IBP - Institute of Bioengineering of the Skin - EVIC Brasil Ltda, São Paulo, Brazil \\ Email: mvrobles@usp.br
}

\begin{abstract}
Among all forms of treatment for cellulite, the most commonly used and easy to access are the cosmetic products containing active substances which are vessel-protective, anti-inflammatory, peripheral microcirculation stimulants and lipolytic agents. In this work, the clinical anticellulite efficacy of a commercial extract of Trichilia catigua (Catuaba) and Ptychopetalum olacoides Bentham (Marapuama) was evaluated. Twenty-seven woman subjects between the ages of 20 and 40 years old with moderate gynoid lipodystrophy participated in this study. The Trichilia catigua and Ptychopetalum olacoides Bentham extract was incorporated into a cosmetic emulsion, and the subjects applied this formulation once a day for 60 days. The following parameters were assessed: hypodermic layer thickness by B-mode ultrasonography, cutaneous temperature, and anthropometric measurements. The test product caused an increase in skin temperature after 60 days application without affecting the hypodermic layer thickness. In addition, a statistically significant reduction in circumference of specific body areas was observed (stomach, waist, upper thigh, upper leg, and upper hip). Thus, the results indicated that the Trichilia catigua and Ptychopetalum olacoides Bentham extract was effective in the reduction of the gynoid lipodystrophy aspect, likely by reducing edema and improving local microcirculation.
\end{abstract}

Keywords: gynoid lipodystrophy, extract, ultrasonography, anthropometric test, cutaneous temperature

\section{Resumo}

Entre todas as formas de tratamento da celulite, as mais utilizados e de fácil acesso são os produtos cosméticos contendo substâncias ativas que são protetoras de vasos, anti-inflamatórios, estimulantes de microcirculação periférica e agentes lipolíticos. Neste trabalho, avaliou-se a eficácia clínica anticelulite de um extrato comercial de Trichilia catigua (Catuaba) e Ptychopetalum olacoides Bentham (Marapuama). Participaram deste estudo 27 mulheres voluntárias entre 20 e 40 anos com hidrolipodistrofia ginoide moderada. O extrato de Trichilia catigua e Ptychopetalum olacoides Bentham foi incorporado em uma emulsão cosmética e os voluntários aplicaram esta formulação uma vez por dia, durante 60 dias. Foram avaliados os seguintes parâmetros: espessura da camada hipodérmica por ultrassonografia em modo B, temperatura cutânea e medidas antropométricas. O produto testado propiciou aumento na temperatura da pele após 60 dias de aplicação sem afetar a espessura da camada hipodérmica. Além disso, observou-se uma redução estaticamente significativa na circunferência de áreas corporais específicas (estômago, cintura, parte superior da coxa, parte superior da perna e quadril superior). Assim, os resultados indicaram que o extrato de Trichilia catigua e Ptychopetalum olacoides Bentham foi efetivo na redução do aspecto da hidrolipodistrofia ginoide, provavelmente pela redução do edema e pela melhoria da microcirculação local.

Palavras-chave: hidrolipodistrofia ginoide, extrato, ultrassonografia, exame antropométrico, temperatura cutânea 


\section{Introduction}

The gynoid lipodystrophy, popularly known as "cellulite", is an alteration of the cutaneous surface, which occurs in 80 to $90 \%$ of post-adolescent women and affects mainly the pelvic region, inferior members, and abdomen. It causes the skin to have "orange peel" appearance and although it is not considered a disease [1], it can causes a reduction in the self-esteem [2].

The mechanisms involved in the formation of cellulite is multifactorial, as it involves a fat metabolism disorder, microcirculation collapse, and the accumulation of fluid in the tissue. In cellulite, it is known that there are structural alterations in the dermis, adipocytes, and microcirculation. The adipocytes present morphological, biochemical, histochemical and ultrastructural alterations [3]. The absence of effective lymphatic drainage, increased deposition of mucopolysaccharides, and the action of estrogens also contribute to this condition $[4,5]$.

Gynoid lipodystrophy can be classified into four stages according to the clinical and histopathological aspects $[2,6]$ :

Grade I - no symptoms, no observed clinical alterations. Histopathology detects some changes such as an increase in capillary permeability and alterations in the adipocytes' shape.

Grade II - presence of clinical alterations such as skin pallor, lower temperature, and decreased elasticity. There is no visible "orange peel" roughness on the skin, without compression or muscular contraction. Additional anatomical changes are detected by histopathology.

Grade III - the skin presents visible "orange peel" roughness while in rest. Thin granulations...detected by palpation, including pain during palpation, a decrease in elasticity, skin pallor, and lower skin temperature . Additional anatomical changes also can be detected by histopathology.

Grade IV - all grade III characteristics are present, with more visible, palpable, and painful lumps, which adhere to deep structures in the skin. The skin presents a wavy appearance. There are additional changes visible via histopathology.

The most commonly used and easy to access cellulite treatments are cosmetic products containing active substances which are vessel-protective, anti-inflammatory, peripheral microcirculation stimulants and lipolytic agents [7] which aim to restore the normal structure of the subcutaneous tissue. Examples of widely used active substances or plant extracts for the treatment of cellulite are methylxanthines (caffeine, theobromine and

\section{Introdução}

A hidrolipodistrofia ginoide, popularmente conhecida como "celulite", é uma alteração da topografia cutânea, que ocorre em 80 a $90 \%$ das mulheres pós-adolescentes e afeta principalmente a região pélvica, membros inferiores e abdômen. Isso faz com que a pele tenha aparência de "casca de laranja" e, embora não seja considerada uma doença [1], provoca uma redução na autoestima [2].

Os mecanismos envolvidos na formação da celulite são multifatoriais, uma vez que envolve um distúrbio do metabolismo da gordura, colapso da microcirculação e acumulação de líquido no tecido. No que diz respeito à celulite, há alterações estruturais na derme, adipócitos e microcirculação. Os adipócitos apresentam alterações morfológicas, bioquímicas, histoquímicas e ultraestruturais [3]. A ausência de drenagem linfática efetiva, o aumento da deposição de mucopolissacarídeos e a ação dos estrogênios também contribuem para essa condição [4,5].

A hidrolipodistrofia ginoide pode ser classificada em quatro estágios de acordo com os aspectos clínicos e histopatológicos $[2,6]$ :

Grau I - sem sintomas, sem alterações clínicas observadas. A histopatologia detecta algumas alterações, como um aumento na permeabilidade capilar e alterações na forma dos adipócitos.

Grau II - presença de alterações clínicas como palidez da pele, menor temperatura e menor elasticidade. Não há aspecto visível de "casca de laranja" e rugosidade para a pele, somente após a compressão ou contração muscular. Alterações anatômicas adicionais são detectadas pela histopatologia.

Grau III - a pele apresenta aspecto visível de "casca de laranja" mesmo em repouso. As granulações finas nos níveis profundos da pele são detectadas pela palpação; Dor durante a palpação; Diminuição da elasticidade; Palidez da pele; Temperatura mais baixa. Há também mais alterações anatômicas que podem ser detectadas pela histopatologia.

Grau IV - todas as características do grau III estão presentes, com nódulos mais visíveis, palpáveis e dolorosos, que aderem a estruturas profundas da pele. A pele apresenta uma aparência ondulada. Existem alterações adicionais na histopatologia.

Entre todas as alternativas de tratamento da celulite, as mais utilizadas e acessíveis são os produtos cosméticos contendo substâncias ativas que são protetoras de vasos, anti-inflamatórias, estimulantes da microcirculação periférica e agentes lipolíticos [7] que visam restaurar a estrutura normal do tecido subcutâneo. Exemplos de 
theophylline) [7], bladderwrack (Fuccus vesiculosus L.), butcher's broom (Ruscus aculeatus), ginkgo (Ginkgo biloba L.), artichoke (Cynara scolymus), common ivy (Hedera helix), ground ivy (Glechoma hederaceae L.), Centella Asiatica and red grapes (Vitis vinifera) [8], the later two of which are rich in several substances like flavonoids and saponins.

Flavonoids are antioxidants that act by reducing lipoperoxidation, capillary permeability, and fragility, enhancing blood and lymphatic circulation. Saponins are anti-inflammatory, anti-edema and capillary protectors $[8,9]$. These classes of substances are found in great concentrations in some Brazilian trees, for example "Catuaba do Norte" and "Marapuama".

The species registered in the Brazilian Pharmacopoeia as true Catuaba is Anemopaegma arvense (Veil.) Stellfeld (Bignoniaceae)[10]. Their roots are used for medicinal proposes. However, Trichilia catigua A. Juss (Meliaceae) is also used in Brazil as Catuaba. This tree is also known as catiguá, catiguá vermelho, pau ervilha and catuaba do norte [11]. In this species, the bark has medicinal uses. The potential efficacy of these extracts is based on their phytochemical composition, as there is a synergic effect of their components (flavonoids, alkaloids, tannins, aromatic oils, saponins, terpenes, steroids, fatty resins, behenic acid and lupeol) $[12,13]$ which have been shown to have lipolytic action and prevent gynoid lipodystrophy [14]. Ptychopetalum olacoides Bentham, known as Marapuama (and/ or Muirapuama and Mirantã among others) in Brazil, contains alkaloids, phenolic compounds, tannins, saponins, flavonoids and terpenic compounds in the roots [15].

Because of their composition, Trichilia catigua A. Juss and Ptychopetalum olacoides Bentham extracts have the potential to improve cellulite appearence. In this research work, a commercial mixture containing both plant extracts was added to an $\mathrm{O} / \mathrm{W}$ (oil in water) cosmetic emulsion. Differing techniques were used to evaluate the efficacy of the plant extract mixture for the treatment of cellulite on subjects: evaluation of the cutaneous temperature, hypodermis thickness by B-type ultrasonography, and anthropometrical analysis. substâncias ativas ou extratos de plantas amplamente utilizados para o tratamento da celulite são as metilxantinas (cafeína, teobromina e teofilina) [7], gilbarbeira (Ruscus aculeatus), ginkgo (Ginkgo biloba L.), bodelha (Fuccus vesiculosus L.), alcachofra (Cynara scolymus), hera comum (Hedera helix), hera moída (Glechoma hederaceae L.), Centella Asiatica e uvas vermelhas (Vitis vinifera) [8], que são ricas em várias substâncias como flavonoides e saponinas.

Os flavonoides são antioxidantes que atuam reduzindo a lipoperoxidação, a permeabilidade capilar e a fragilidade, aumentando a circulação sanguínea e linfática. Saponinas são anti-inflamatórios, anti-edema e protetores capilares [8,9]. Essas classes de substâncias são encontradas em grandes concentrações em algumas árvores brasileiras, como a "Catuaba do Norte" e a "Marapuama".

As espécies registradas na Farmacopéia Brasileira como Catuaba verdadeira são Anemopaegma arvense (Veil.) Stellfeld (Bignoniaceae) [10]. Suas raízes são usadas para propósitos medicinais. No entanto, Trichilia catigua A. Juss (Meliaceae) também é utilizada no Brasil como Catuaba. Esta árvore também é conhecida como catiguá, catiguá vermelho, pau ervilha e catuaba do norte [11]. Neste caso, a casca tem aplicações medicinais. A eficácia potencial destes extratos é baseada na sua composição fitoquímica, uma vez que existe um efeito sinérgico dos seus componentes (flavonoides, alcaloides, taninos, óleos aromáticos, saponinas, terpenos, esteroides, resinas graxas, ácido beénico e lupeol) $[12,13]$. Apresenta ação lipolítica e previne a hidrolipodistrofia ginóide [14]. Ptychopetalum olacoides Bentham conhecido como Marapuama (e/ou Muirapuama e Mirantã entre outros) no Brasil contém alcaloides, compostos fenólicos, taninos, saponinas, flavonoides e compostos terpênicos nas raízes [15].

Devido à sua composição, os extratos de Trichilia catigua A. Juss e Ptychopetalum olacoides Bentham apresentam potencial para melhorar o aspecto da celulite. Neste trabalho de pesquisa, adicionou-se uma mistura comercial contendo ambos os extratos de plantas a uma emulsão cosmética O/A (óleo em água). Diferentes técnicas foram utilizadas para avaliar a eficácia da mistura de extratos vegetais para o tratamento da celulite em voluntários: avaliação da temperatura cutânea, espessura da hipoderme por ultrassonografia tipo $\mathrm{B}$ e análise antropométrica. 


\section{Material and Methods}

\section{Subjects}

A total of 43 female subjects between the ages between of 20 and 40 years old, with moderate classified as grade I to III gynoid lipodystrophy in the abdomen, buttock and thighs, [6] and with no skin diseases were included in this study. Each subject signed a written consent before the initiation of the study. The study was approved by the Independent Ethics Committee and was conducted in accordance with the Declaration of Helsinki principles.

All subjects agreed to the following restrictions: no application of anticellulite or fat reduction products other than the ones tested during the study; no exposure to intense radiation (natural or artificial); no changing hygiene care, physical activity and dietary habits; no other anti-cellulite treatments, such as lymphatic drainage, mesotherapy, sauna and others; no use of drugs such as appetite inhibitors, tranquilizers, antidepressants, diuretics, laxatives or psychotropics; no skin exfoliation with chemical or mechanical methods/products in the experimental area; no tight clothing; no change of contraceptive method (if used). Additionally, subjects were to report to the Research Institute on the pre-scheduled days.

The exclusion criteria included non-compliance with the requirements mentioned above; pregnancy detected during the study; body weight variation above $5 \%$ of initial weight.

\section{Formulations}

The formulations, prepared as oil in water $(\mathrm{O} / \mathrm{A})$ emulsions, were a placebo (base formulation), a positive control containing methyl nicotinate, and the test product containing an hydroglycolic extract of Trichilia catigua and Ptychopetalum olacoides Bentham (Table 1). Placebo and positive control formulations were applied only on day 1 (D1) at the Research Institute. The tested product containing the hydroglycolic extract of Trichilia catigua and Ptychopetalum olacoides Bentham was provided to the subjects by the researcher with all necessary instructions for the correct use of the product. The subjects were advised to use the product at home from day 2 (D2) until the end of study period (D60) on the abdomen, hip, thigh and legs every day after showering, on dry skin. The amount of product applied daily was not previously defined by the researcher, but it was estimated by weighing the package containing the test product at the beginning of the study (D1) and on the

\section{Material e Métodos}

\section{Voluntários}

Um total de 43 mulheres voluntárias entre 20 e 40 anos com hidrolipodistrofia ginóide moderada no abdômen, nádegas e coxas, classificadas como grau I a III [6] e sem doenças de pele foram incluídas neste estudo. Cada voluntário assinou um consentimento por escrito antes do início do estudo. O estudo foi aprovado pelo Comitê de Ética e foi conduzido de acordo com os princípios da Declaração de Helsinki.

Todos os voluntários devem obedecer aos seguintes requisitos: não aplicar produtos anticelulite nem de redução de gordura além dos testados durante o estudo; não se expor à radiação intensa (nem natural nem artificial); não alterar hábitos de higiene, atividade física e alimentares; não realizar outros tratamentos anticelulite, tais como drenagem linfática, mesoterapia, sauna e outros; não consumir medicamentos como inibidores do apetite, tranquilizantes, antidepressivos, diuréticos, laxantes ou psicotrópicos; não realizar esfoliação da pele com métodos/produtos químicos ou mecânicos na área experimental; não usar roupas apertadas; não alterar o método contraceptivo; ir para o Instituto de Pesquisa nos dias pré-estabelecidos.

Os critérios de exclusão foram: não atendimento aos requisitos de estudo acima mencionados, gravidez detectada durante o estudo, variação de peso corporal acima de $5 \%$ em relação ao peso inicial e fatores capazes de interromper a participação do voluntário no estudo.

\section{Formulações}

As formulações, preparadas sob a forma de emulsões de óleo em água $(\mathrm{O} / \mathrm{A})$, compreendiam um placebo (formulação base), um controle positivo contendo nicotinato de metila e o produto teste contendo extrato hidroglicólico de Trichilia catigua e Ptychopetalum olacoides Bentham (Tabela 1).

As formulações placebo e controle positivo foram aplicadas apenas no dia 1 (D1) no Instituto de Pesquisa. $\mathrm{O}$ produto teste contendo o extrato hidroglicólico de Trichilia catigua e Ptychopetalum olacoides Bentham foi fornecido pelo pesquisador aos voluntários, que receberam todas as instruções necessárias para o uso correto do produto. Os voluntários foram aconselhados a utilizar o produto em casa a partir do dia 2 (D2) até ao final do período de estudo (D60) no abdômen, quadril, coxa e pernas todos os dias após o banho, na pele seca. A quantidade de produto aplicado diariamente não foi previamente definida pelo pesquisador, mas foi monitorada pesando-se a embalagem contendo o produto 
following days of evaluation (after 30 and 60 days from the start - D30 and D60, respectively). teste no início do estudo (D1) e nos dias de avaliação seguintes (após 30 e 60 dias a partir do início - D30 e D60, respectivamente).

Table 1/ Tabela 1 - Qualitative and quantitative composition of the cosmetic formulations/ Composição quali-quantitativa das formulações cosméticas. *INCI: International Nomenclature of

Cosmetic Ingredient

\begin{tabular}{cccc}
\hline Ingredients/ Ingredientes $\left({ }^{*}\right.$ INCI) & Placebo & $\begin{array}{c}\text { Test Product/ } \\
\text { Produto teste }\end{array}$ & $\begin{array}{c}\text { Positive Control/ } \\
\text { Controle positivo }\end{array}$ \\
\hline Polyacrylamide & 3.0 & 3.0 & 3.0 \\
\hline Isononyl isononanoate & 3.0 & 3.0 & 3.0 \\
\hline Myristyl Lactate & 1.0 & 1.0 & 1.0 \\
\hline Disodium EDTA & 0.1 & 0.1 & 0.1 \\
\hline Phenoxyethanol & 0.5 & 0.5 & 0.5 \\
\hline Cyclomethicone & 1.0 & 1.0 & 1.0 \\
\hline Methyl Nicotinate & - & - & 0.1 \\
\hline Extract of Trichilia catigua and & - & 5.0 & 100 \\
\hline Ptychopetalum olacoides Bentham & 100 & 100 & \\
\hline Aqua q.s.p & & &
\end{tabular}

Legend/ Legenda: (-) absence of the component/ ausência do componente

\section{Study design}

We conducted a monocentric, open and controlled clinical trial. The study period per subject was $60 \pm 3$ days. Table 2 comprises the days of evaluation (D1, D30 and D60), parameters and regions analyzed, along with the products used in each time period. The parameters analyzed during the study period were: cutaneous temperature, hypodermic layer thickness, weight, height and circumference of predetermined areas of the body. This study was intra-individually controlled, in other words, the control was performed in each of the participants of the research in specific body areas for this purpose. The control and treatment areas were pre-established and when applicable, were randomized. Additional parameters were observed during the study, such as body weight, daily log of eating habits and physical activity. In order to avoid deviations in the results, the range of weight variation was quite restrictive, thus participants were asked to maintain their normal eating habits and physical activities.

The compliance control was performed by means of questionnaire answered by subjects on the days of analysis (D30 and D60). This questionnaire contained questions about the number of applications performed (considering the days of application and frequency),

\section{Desenho do estudo}

Realizou-se um ensaio clínico monocêntrico, aberto e controlado. $\mathrm{O}$ estudo foi realizado de acordo com os princípios da Declaração de Helsinki e aprovado pelo Comitê de Ética. O Consentimento Informado foi obtido de todos os participantes do estudo antes do início. O período de estudo por paciente foi de $60 \pm 3$ dias. A Tabela 2 compreende os dias de avaliação (D1, D30 e D60), parâmetros e regiões analisadas, além dos produtos utilizados em cada período de tempo. Os parâmetros analisados durante o período de estudo foram: temperatura cutânea, espessura da camada hipodérmica, peso, altura e circunferência de áreas predeterminadas do corpo. Este estudo foi intra-individualmente controlado, ou seja, o controle foi realizado em cada um dos participantes da pesquisa em áreas específicas do corpo para este fim. As áreas de controle e tratamento foram pré-estabelecidas e, quando aplicável, foram randomizadas. Além disso, alguns parâmetros foram observados durante o estudo, como peso corporal, hábitos alimentares diários e atividade física. Os participantes não podiam alterar seus hábitos alimentares ou atividades físicas, e a variação de peso era bastante restritiva, a fim de evitar desvios nos resultados. O controle de conformidade foi realizado por meio de um questionário 
Table 2/Tabela 2 - Experimental conditions/Condições experimentais

\begin{tabular}{|c|c|c|c|c|}
\hline Day/Dia & $\begin{array}{c}\text { Experimental } \\
\text { time/ Tempo } \\
\text { experimental } \\
\end{array}$ & Parameter/ Parâmetro & Region/ Região & $\begin{array}{l}\text { Product/ } \\
\text { Produto }\end{array}$ \\
\hline D1 & T0 & $\begin{array}{c}\text { Initial interview, weight, } \\
\text { height and body } \\
\text { circumference/ } \\
\text { Entrevista inicial, } \\
\text { peso, altura e } \\
\text { circunferência corporal }\end{array}$ & $\begin{array}{c}\text { stomach, waist, } \\
\text { hip, thigh and } \\
\text { leg/ } \\
\text { estômago, } \\
\text { cintura, quadril, } \\
\text { coxa e perna } \\
\end{array}$ & - \\
\hline D1 & T0 & $\begin{array}{l}\text { Cutaneous temperature/ } \\
\text { Temperatura cutânea }\end{array}$ & $\begin{array}{l}\text { handle/ } \\
\text { punho }\end{array}$ & - \\
\hline D1 & $\begin{array}{c}\text { T20', T30' and } \\
\text { T440' }\end{array}$ & $\begin{array}{l}\text { Cutaneous temperature/ } \\
\text { Temperatura cutânea }\end{array}$ & $\begin{array}{l}\text { handle/ } \\
\text { punho }\end{array}$ & $\mathrm{P}, \mathrm{P}+, \mathrm{TP}$ \\
\hline D1 & T0 & $\begin{array}{c}\text { Hypodermic layer } \\
\text { thickness/ } \\
\text { Espessura da camada } \\
\text { hipodérmica }\end{array}$ & $\begin{array}{l}\text { abdomen, thighs } \\
\text { and forearm } \\
\text { (control) / } \\
\text { abdome, coxas e } \\
\text { antebraço } \\
\text { (controle) } \\
\end{array}$ & - \\
\hline D30/D60 & - & $\begin{array}{c}\text { Hypodermic layer } \\
\text { thickness/ } \\
\text { Espessura da camada } \\
\text { hipodérmica }\end{array}$ & $\begin{array}{l}\text { abdomen, thighs } \\
\text { and forearm } \\
\text { (control)/ } \\
\text { abdome, coxas e } \\
\text { antebraço } \\
\text { (controle) }\end{array}$ & $\mathrm{TP}$ \\
\hline D30/D60 & - & $\begin{array}{l}\text { Weight, height, body } \\
\text { circumference/ } \\
\text { Peso, altura e } \\
\text { circunferência corporal }\end{array}$ & $\begin{array}{l}\text { stomach, waist, } \\
\text { hip, thigh and } \\
\text { leg/ } \\
\text { estômago, } \\
\text { cintura, quadril, } \\
\text { coxa e perna }\end{array}$ & TP \\
\hline
\end{tabular}

body area applied, the amount of product applied (calculated by the difference between the weight of the test product package before and after the analysis period). The subjects were also asked whether other people used the product or if it was applied over regions of the body not covered by the study.

Both placebo and positive control formulations were applied only on the first day (D1) on handle (right or left, randomly determined) and skin temperature was evaluated after application of the formulations (20, 30 and 40 minutes), using an infrared thermometer (Raynger ST60 ProPlus, Santa Cruz, CA, USA), with the purpose of assessing the subjects' response to the formulations. On the following analysis days (D30 and D60), the temperature of the skin of the abdomen, arms and thighs areas, as shown in Figure 1, was assessed. respondido pelos voluntários nos dias de análise (D30 e D60). Este questionário continha perguntas sobre o número de aplicações realizadas (considerando os dias de aplicação e frequência), região aplicada, a quantidade de produto aplicada (calculada pela diferença entre o peso da embalagem do produto antes e depois do período de análise). Os voluntários também foram questionados se outras pessoas usaram o produto ou se ele foi aplicado a regiões do corpo não cobertas pelo estudo.

As formulações placebo e controle positivo foram aplicadas apenas no primeiro dia (D1) no punho (direito ou esquerdo, aleatoriamente determinado) e a temperatura da pele foi avaliada após a aplicação das formulações (20, 30 e $40 \mathrm{~min})$, utilizando um termômetro infravermelho Raynger ST60 ProPlus, Santa Cruz, CA, EUA), com o objetivo de avaliar a resposta dos voluntários 
The assays were carried five times for each body area, under the same experimental conditions, per subject and time.

\section{Anthropometric Measurements}

Weight, height and circumference of some body areas [16] were assessed by qualified technicians. Body Mass Index (BMI) was calculated through the ratio mass/ height $\mathrm{t}^{2}$ and expressed in $\mathrm{kg} / \mathrm{m}^{2}$. Both the weight and height of the subjects were obtained by a single reading on the experimental times (D1, D30 and D60), using an anthropometrical scale for weight and height. The circumference measurements were determined 10 times in each area (shown in Figure 2).

perante as formulações. Nos dias de análise seguintes (D30 e D60), foi avaliada a temperatura da pele das áreas do abdômen, braços e coxas, como mostrado na Figura 1. Os ensaios foram realizados cinco vezes para cada região do corpo, nas mesmas condições experimentais, por voluntário e tempo.

\section{Medições antropométricas}

O peso, altura e circunferência de algumas áreas do corpo [16] foram avaliados por técnicos qualificados. O Índice de Massa Corporal (IMC) foi calculado através da relação massa/altura ${ }^{2}$ e expresso $\mathrm{em} \mathrm{kg} / \mathrm{m}^{2}$. O peso e a altura dos voluntários foram obtidos por uma única leitura nos tempos experimentais (D1, D30 e D60), utilizando uma escala antropométrica para peso e altura. As medições da circunferência foram determinadas 10 vezes em cada área (mostrada na Figura 2).

No início do estudo (D1), os voluntários permanece-

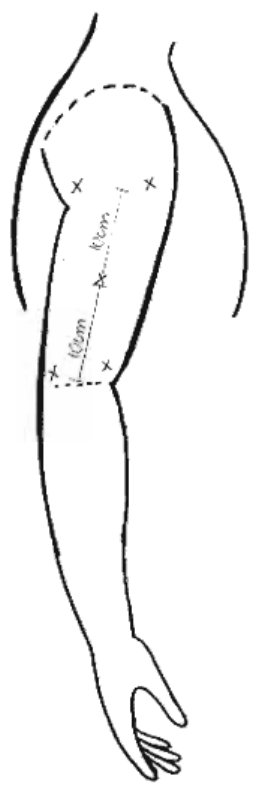

B

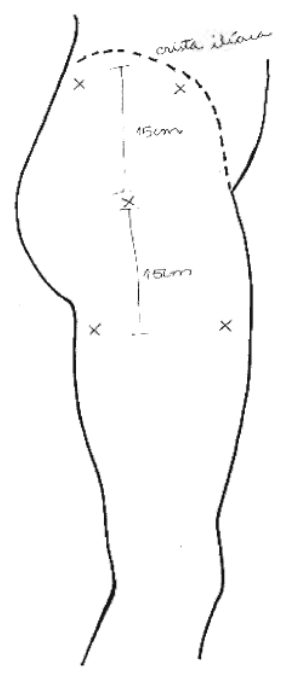

C

A

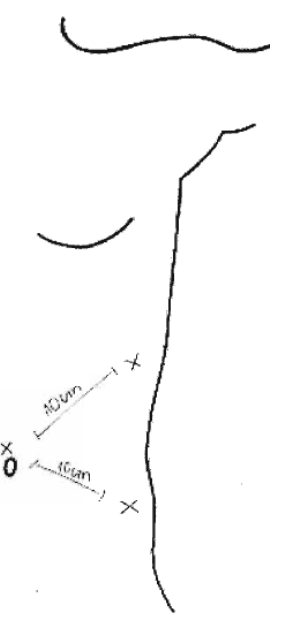

Figure 1/ Figura 1 - Experimental areas adopted for the measurement of cutaneous temperature in the abdomen (A), forearm (B) and thigh (C)/ Regiões experimentais adotadas para mensuração da temperatura cutânea no abdômen (A), antebraço (B) e coxa (C) 


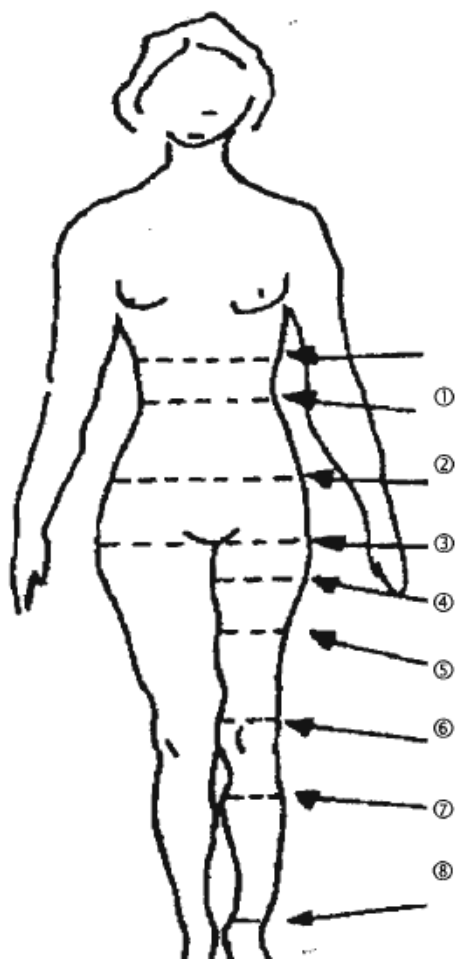

Figure 2/ Figura 2 - Areas used for circumference measurement. Legend: (1) stomach and waist; (2) upper hip (edge of the iliac crest); (3) lower hip (pubic symphysis); (4) upper thigh; (5) medial thigh; (6) lower thigh; (7) upper leg; (8) lower leg/ Regiões utilizadas para medição da circunferência. Legenda: (1) estômago e cintura; (2) quadril superior (borda da crista ilíaca); (3) quadril inferior (sínfise púbica); (4) parte superior da coxa; (5) coxa mediana; (6) coxa inferior; (7) perna superior; (8) parte inferior da perna.

At the beginning of the study (D1), subjects remained in a room for 20 minute at $22 \pm 2^{\circ} \mathrm{C}$ and relative humidity of $55 \pm 5 \%$ for acclimatization. Afterward, they were taken to the evaluation room with identical environmental conditions. The subjects remained at the supine position and were placed in an appropriate apparatus for standardizing the areas where the measurements were performed. The circumference was determined in the following areas: stomach, waist, upper hip (edge of the iliac crest), lower hip (pubic symphysis), thigh (upper, medial and lower) and leg (upper and lower), as presented in Figure 2.

\section{Hypodermic layer thickness}

On day D1, hypodermic layer thickness measurements were performed by a radiologist before application of any product. The experimental areas were the same as those adopted for temperature evaluation (Figure 1): the lower part of the abdomen (between the umbilical scar and the upper border of the pubic symphysis), the medial portion of the right arm (between the ulnar fossa and the axilla; used as control), and the proximal region of the thigh $(15 \mathrm{~cm}$ away from the right or left iliac ram numa sala durante 20 min a $22 \pm 2^{\circ} \mathrm{C}$ e umidade relativa de $55 \pm 5 \%$ para aclimatização. Posteriormente, foram levados para a sala de avaliação com condições idênticas. Os voluntários permaneceram na posição supina e foram colocados em um aparelho apropriado para padronização das áreas onde as medições foram realizadas. A circunferência foi determinada nas seguintes áreas: estômago, cintura, quadril superior (borda da crista ilíaca), quadril inferior (sínfise púbica), coxa (superior, mediana e inferior) e perna (superior e inferior), conforme apresentado na Figura 2.

\section{Espessura da camada hipodérmica}

No dia D1, as medições da espessura da camada hipodérmica foram realizadas por um radiologista antes da aplicação de qualquer produto. As regiões experimentais foram as mesmas adotadas para a avaliação da temperatura (Figura 1): parte inferior do abdômen (entre a cicatriz umbilical e a borda superior da sínfise púbica), a porção medial do braço direito (entre a fossa ulnar e a axila, utilizada como controle), e a região proximal da coxa (15 cm de distância da crista ilíaca direita ou esquerda, de acordo com a randomização). As regiões 
crest, according to randomization). The thigh and abdomen areas received an application of the tested product. The arm was considered the control area since no product was applied. The hypodermic layer thickness measurements were performed on days D1, D30 and D60 five times at each experimental day, per region/ subject. The hypodermic layer thickness parameter was assessed with a B-mode ultrasonography (Phillips ATL HDI 5000; ATL Ultrasound, Washington, USA), using linear transducer L12-5 and frequency of 5-12 MHz, by measuring the distance between the muscular fascia and the bottom of the stratum corneum at a single point.

\section{Data Analysis}

Statistical analysis was performed using linear models considering the repeated measurements and each body area, using the SAS 8.2 (SAS Institute, Cary, NC) system, under operational system Linux (Mandrake Linux 10.1). The model evaluated the effect of the treatment, time and interaction among these variables.

\section{Results and Discussion}

A total of 43 women were initially included in the study. All met the inclusion criteria required in the protocol. Out of the 43 subjects included, 38 attended the Research Institute on the first day (D1) for skin temperature measurement. During the use of the test product at home, 16 subjects decided to leave the study. Among the reasons stated by these subjects were personal problems, unpleasant smell of the product, and health problems. Therefore, 27 subjects participated in the complete study.

\section{Cutaneous Temperature}

The cutaneous temperature varies according to the body's region, from $32^{\circ} \mathrm{C}$ in the extremities to $35^{\circ} \mathrm{C}$ in the remaining regions of the body. It is regulated through a thermoregulation mechanism, particularly in situations of hot or cold. Endogenous factors contribute to altering cutaneous temperature which varies depending on the body region due to variations in blood perfusion at skin level. The employment of equipment such as cutaneous thermometers allows the measurement of these variations $[17,18]$.

Initially, the positive control comprised of methyl nicotinate caused an increase in the skin temperature, from 31.94 to $32.46^{\circ} \mathrm{C}, 40$ minutes following the application, unlike placebo and the test product. The observed increase in this parameter was expected as methyl nicotinate is rubefacient and vasodilator [19]. In the same period of time, the test product containing Trichilia da coxa e do abdômen receberam uma aplicação do produto teste. A região do braço foi considerada área controle, pois nenhum produto foi aplicado. As medidas da espessura da camada hipodérmica foram realizadas nos dias D1, D30 e D60, cinco vezes em cada dia experimental, por região/voluntário. A espessura da camada hipodérmica foi avaliada por ultrassonografia em modo B (Phillips ATL HDI 5000, ATL Ultrasound, Washington, EUA), utilizando o transdutor linear L125 e frequência de $5-12 \mathrm{MHz}$, medindo a distância entre a fascia muscular e a profundidade do estrato córneo em um único ponto.

\section{Análise de dados}

A análise estatística foi realizada utilizando modelos lineares considerando as medidas repetidas e cada região do corpo, utilizando o sistema SAS 8.2 (SAS Institute, Cary, NC), sob o sistema operacional Linux (Mandrake Linux 10.1). O modelo avaliou o efeito do tratamento, tempo e interação entre essas variáveis.

\section{Resultados e Discussão}

Um total de 43 mulheres foram inicialmente incluídas no estudo. Todas preencheram os critérios de inclusão exigidos no protocolo. Dos 43 voluntários incluídos, 38 estiveram no Instituto de Pesquisa no primeiro dia (D1) para a medição da temperatura da pele. Durante o uso do produto teste, em casa, 16 voluntários retiraram-se e não completaram o estudo. Entre as razões indicadas pelos voluntários, estão: problemas pessoais, cheiro desagradável do produto e problemas de saúde. Portanto, no final, participaram 27 voluntários no estudo completo.

\section{Temperatura Cutânea}

A temperatura cutânea varia de acordo com a região do corpo, de $32^{\circ} \mathrm{C}$ nas extremidades a $35^{\circ} \mathrm{C}$ nas demais regiões do corpo. É regulado através de um mecanismo de termorregulação, particularmente em situações de calor ou frio. Fatores endógenos contribuem para alterar a temperatura cutânea, que varia dependendo da região do corpo, devido a variações na perfusão sanguínea ao nível da pele. O emprego de equipamentos como termômetros cutâneos permite a mensuração dessas variações $[17,18]$.

Inicialmente, o controle positivo composto por nicotinato de metila causou aumento da temperatura da pele, de 31,94 a $32,46^{\circ} \mathrm{C}$, após 40 min de aplicação, ao contrário do placebo e do produto teste. O aumento observado neste parâmetro já era esperado, uma vez que o nicotinato de metila é rubofaciente e vasodilatador [19]. 
catigua and Ptychopetalum olacoides Bentham extracts did not increase the cutaneous temperature. There are some considerations that may explain the results obtained with the test product, such as single application of the product and immediate evaluation (on T20, T30 and T40), low concentration of the extract (insufficient to promote alterations of cutaneous temperature), and/ or low concentration of active substances in the extracts (insufficient to alter skin temperature significantly).

However, after prolonged and continuous application of the test product (60 days), a significant change in skin temperature was observed ( $p$-value $<0.05$ ), as observed in Table 3, while in the control area (arms), no significant variation was detected.
No mesmo período de tempo, o produto teste contendo extratos de Trichilia catigua e Ptychopetalum olacoides Bentham não aumentou a temperatura cutânea. Há algumas considerações que podem explicar os resultados obtidos com o produto teste, como a aplicação única do produto e a avaliação imediata (T20, T30 e T40 min); baixa concentração do extrato (insuficiente para promover alterações da temperatura cutânea); baixa concentração de substâncias ativas nos extratos (não é suficiente para alterar significativamente a temperatura da pele).

No entanto, após aplicação prolongada e contínua do produto teste (60 dias), observou-se uma alteração significativa na temperatura da pele $(\mathrm{p}<0,05)$, conforme observado na Tabela $\mathbf{3}$, enquanto na região controle (braços) não foi detectada qualquer variação significativa.

Table 3/ Tabela 3 - Least squares means of cutaneous temperature from D1 to D60 $\left({ }^{\circ} \mathrm{C}\right) /$ Média dos Quadrados Mínimos da temperatura cutânea de D1 a D60 $\left({ }^{\circ} \mathrm{C}\right) . \mathrm{n}=27$

\begin{tabular}{|c|c|c|c|c|c|c|c|c|c|c|}
\hline \multirow{2}{*}{\multicolumn{2}{|c|}{ Data/ Dados }} & \multicolumn{9}{|c|}{ Least squares means/ Média dos Quadrados Mínimos $\left({ }^{\circ} \mathrm{C}\right)$} \\
\hline & & \multicolumn{3}{|c|}{ Abdomen } & \multicolumn{3}{|c|}{$\begin{array}{c}\text { Arm/ Braço } \\
\text { (control/controle) }\end{array}$} & \multicolumn{3}{|c|}{ Thigh/ Coxa } \\
\hline \multicolumn{2}{|c|}{ Day/ Dia } & D1 & D30 & D60 & D1 & D30 & D60 & D1 & D30 & D60 \\
\hline \multicolumn{2}{|c|}{$\begin{array}{l}\text { Estimative/ } \\
\text { Estimativa }\end{array}$} & 31.55 & 32.22 & 32.21 & 30.58 & 30.98 & 30.63 & 29.77 & 30.53 & 30.13 \\
\hline \multirow{2}{*}{$\begin{array}{l}\text { Limits/ } \\
\text { Limites }\end{array}$} & Inferior & 31.17 & 31.81 & 31.77 & 30.23 & 30.60 & 30.22 & 29.36 & 30.09 & 29.65 \\
\hline & Superior & 31.93 & 32.63 & 32.65 & 30.93 & 31.36 & 31.04 & 30.17 & 30.97 & 30.61 \\
\hline \multicolumn{11}{|c|}{ Statistical Analysis/ Análise Estatística } \\
\hline \multicolumn{2}{|c|}{ DF Num } & \multicolumn{3}{|c|}{2} & \multicolumn{3}{|c|}{2} & \multicolumn{3}{|c|}{2} \\
\hline \multicolumn{2}{|c|}{ DF Den } & \multicolumn{3}{|c|}{57} & \multicolumn{3}{|c|}{57} & \multicolumn{3}{|c|}{57} \\
\hline \multicolumn{2}{|c|}{ F statistic } & \multicolumn{3}{|c|}{5.57} & \multicolumn{3}{|c|}{1.57} & \multicolumn{3}{|c|}{3.55} \\
\hline \multicolumn{2}{|c|}{ p-value } & \multicolumn{3}{|c|}{0.0062} & \multicolumn{3}{|c|}{0.2163} & \multicolumn{3}{|c|}{0.0353} \\
\hline
\end{tabular}

Legend/ Legenda: DF Num: Degrees of freedom of the numerator/ Graus de liberdade do numerador; DF Den: Degrees of freedom in the denominator/ Graus de liberdade no denominador 


\section{Hypodermic Layer Thickness}

The measurement of the hypodermic layer thickness was chosen because it is an objective, quantitative and standardized method of analysis. The permeation of the employed active substances could improve the decrease of the edema, regulation of the capillary permeability and the restructuration of the conjunctive tissue with a possible reduction of adiposity. These effects might cause variation of the hypodermic thickness which correlates with the anthropometric measurements. However, according to the adopted experimental conditions, no statistically significant changes in hypodermic layer thickness were observed in any of the evaluated areas (Table 4).

\section{Espessura da camada hipodérmica}

A medida da espessura da camada hipodérmica foi escolhida por ser um método de análise objetivo, quantitativo e padronizado. A permeação das substâncias ativas utilizadas poderia melhorar a diminuição do edema, a regulação da permeabilidade capilar e a reestruturação do tecido conjuntivo com uma possível redução da adiposidade. Esses efeitos podem causar variação da espessura hipodérmica que se correlaciona com as medidas antropométricas. No entanto, de acordo com as condições experimentais adotadas, não foram observadas alterações estatisticamente significativas na espessura da camada hipodérmica em nenhuma das regiões avaliadas (Tabela 4)

Table 4/ Tabela 4 - Least squares means of hypodermic layer thickness from subjects using the test product/ Média dos mínimos quadrados da espessura da camada hipodérmica de voluntários usando o produto teste. $\mathrm{n}=27$

\begin{tabular}{|c|c|c|c|c|c|c|c|c|c|c|}
\hline \multirow{2}{*}{\multicolumn{2}{|c|}{ Data/ Dados }} & \multicolumn{9}{|c|}{ Least squares means/ Média dos mínimos quadrados $(\mathrm{cm})$} \\
\hline & & \multicolumn{3}{|c|}{ Abdomen } & \multicolumn{3}{|c|}{$\begin{array}{c}\text { Arm/ Braço } \\
\text { (control/controle) }\end{array}$} & \multicolumn{3}{|c|}{ Thigh/ Coxa } \\
\hline \multicolumn{2}{|c|}{ Day/ Dia } & D1 & D30 & D60 & D1 & D30 & D60 & D1 & D30 & D60 \\
\hline \multicolumn{2}{|c|}{$\begin{array}{l}\text { Estimative/ } \\
\text { Estimativa }\end{array}$} & 3.21 & 3.23 & 3.26 & 0.78 & 0.78 & 0.81 & 3.36 & 3.46 & 3.40 \\
\hline \multirow{2}{*}{$\begin{array}{l}\text { Limits/ } \\
\text { Limites }\end{array}$} & Inferior & 2.93 & 2.94 & 3.53 & 0.73 & 0.66 & 0.69 & 3.10 & 3.19 & 3.73 \\
\hline & Superior & 3.26 & 2.96 & 3.56 & 0.93 & 0.90 & 0.93 & 3.40 & 3.12 & 3.67 \\
\hline \multicolumn{11}{|c|}{ Statistical Analysis/ Análise Estatística } \\
\hline \multicolumn{2}{|c|}{ DF Num } & \multicolumn{3}{|c|}{2} & & 2 & & \multicolumn{3}{|c|}{2} \\
\hline \multicolumn{2}{|c|}{ DF Den } & \multicolumn{3}{|c|}{55} & \multicolumn{3}{|c|}{55} & \multicolumn{3}{|c|}{55} \\
\hline \multicolumn{2}{|c|}{ F statistic } & \multicolumn{3}{|c|}{0.14} & \multicolumn{3}{|c|}{0.51} & \multicolumn{3}{|c|}{1.11} \\
\hline \multicolumn{2}{|c|}{ p-value } & \multicolumn{3}{|c|}{0.8711} & \multicolumn{3}{|c|}{0.6032} & \multicolumn{3}{|c|}{0.3366} \\
\hline
\end{tabular}

Legend/ Legenda: DF Num: Degrees of freedom of the numerator/ Graus de liberdade do numerador; DF Den: Degrees of freedom in the denominator/ Graus de liberdade no denominador 


\section{Anthropometric Measurements}

The results of the adjusted models allowed the verification of the effect of the test product on anthropometric measurements through elapsed time. Statistical influence of time (day) on the model and the averages of least squares, inferior and superior limit of $95 \%$ per time are presented in Table 5. Table 6 shows the analysis of Repeatability and Reproducibility (R\&R) for the body regions.

\section{Medidas Antropométricas}

Os resultados dos modelos ajustados permitiram verificar o efeito do produto teste nas medidas antropométricas no tempo decorrido. A influência estatística do tempo (dia) sobre o modelo e as médias de quadrados mínimos, limite inferior e superior de $95 \%$ por tempo são apresentadas na Tabela 5. A Tabela 6 mostra a análise de Repetibilidade e Reprodutibilidade (R \& R) para as regiões corpóreas.

Table 5/ Tabela 5 - Least squares means of body circumference $(\mathrm{cm})$ from subjects using the test product/ Médias dos mínimos quadrados da circunferência corporal $(\mathrm{cm})$ de voluntários usando o produto teste. $\mathrm{n}=27$

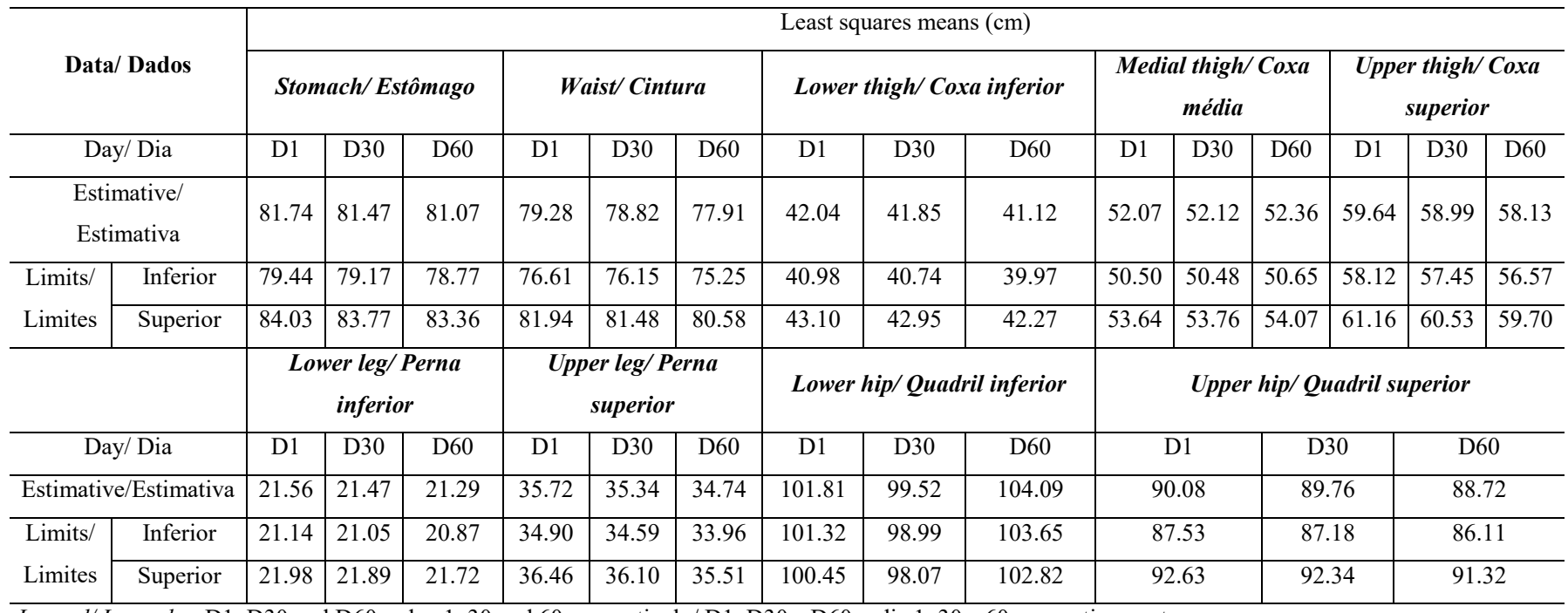

Legend/ Legenda: D1, D30 and D60 = day 1, 30 and 60, respectively/ D1, D30 e D60 = dia 1, 30 e 60, respectivamente

Table 6/ Tabela 6 - Statistical analysis of body areas circumference results for each body area/ Análise estatística dos resultados da circunferência das áreas corporais para cada área do corpo. $\mathrm{n}=27$

\begin{tabular}{|c|c|c|c|c|}
\hline \multirow{2}{*}{ Area/ Área } & \multirow{2}{*}{$\begin{array}{l}\text { Results of the } \\
\text { Measurements/ } \\
\text { Resultados das } \\
\text { Mensurações }\end{array}$} & \multirow{2}{*}{ p-value } & \multicolumn{2}{|c|}{$\begin{array}{l}\text { R\&R analysis/ } \\
\text { Análises R\&R }\end{array}$} \\
\hline & & & $\%$ & $\begin{array}{c}\text { Classification/ } \\
\text { Classificação }\end{array}$ \\
\hline Stomach/ Estômago & + & $<0.0001$ & 30.83 & $\mathrm{I}$ \\
\hline Waist/ Cintura & + & $<0.0001$ & 14.77 & A \\
\hline Lower Thigh/ Coxa inferior & - & 0.1345 & 59.11 & I \\
\hline Medial Thigh/ Coxa média & - & 0.9074 & 92.89 & I \\
\hline Upper Thigh/ Coxa superior & + & 0.0050 & 20.16 & A \\
\hline Lower Leg/ Perna inferior & + & 0.0014 & 33.27 & I \\
\hline Upper Leg/Perna superior & + & 0.0003 & 37.31 & I \\
\hline Lower Hip/ Quadril inferior & - & 0.1322 & 16.02 & A \\
\hline Upper Hip/ Quadril superior & + & 0.0429 & 26.91 & M \\
\hline
\end{tabular}

Legend/Legenda: $(+)$ confirmed reduction of the measurements/ redução confirmada das mensurações; (-) no differences of the measurements/ sem diferenças nas mensurações; I = inadequate results/ resultados inadequados; $\mathrm{A}=$ adequate results/ resultados adequados; $\mathrm{M}=$ marginal results/ resultados marginais; R\&R = Repeatability and Reproducibility/ Repetibilidade e Reprodutibilidade; 
Repeatability of the measuring system is the variation of a measurement taken from the same samples by the same technician. Reproducibility is the additional variation introduced when different technicians use the measuring system to evaluate the same samples. For this reason, this study required two qualified and trained technicians. The proportion of variability due to the R\&R is classified as: $<10 \%$ (excellent); 11 $20 \%$ (adequate); $21-30 \%$ (marginal); and $>30 \%$ (inadequate). Total variability is the sum of two components: the variability of the material that is being measured and of the error measurement which is composed by the variability of different technicians, the interaction of technician and materials, and for the proper measuring system [20,21].

Anthropometric evaluations were used due to their simplicity and low cost. The method consists of assessing weight, height, BMI and body circumference data. It is a quantitative system that can be used as an indirect way of measuring the adipose tissue thickness. Anthropometric measurements are adequate to evaluate obesity and local adiposity, but they do not reflect significantly the cellulite alterations, since subject may present weight loss without any cellulite reduction [22]. Due to its characteristic, it is mandatory for subjects to follow correctly the study protocol requirements.

When evaluating anthropometric data, the subjects' BMI comparison (before and after the application of the cosmetic product) aimed at excluding possible variation of weight as bias which could compromise the result of the research. Once one of the discontinuity criteria involved body weight variation above $5 \%$, no statistically significant difference was observed in this parameter before and after the product's application. Subjects remained with the same average weight, allowing the comparison of the measurements in different experimental times.

As a result of the anthropometric measurements, the application of the cosmetic product containing Trichilia catigua and Ptychopetalum olacoides extracts provided statistically significant differences before and after its application over the following body areas: stomach $(-0.82 \%)$, waist $(-1.73 \%)$, upper thigh $(-2.53 \%)$, upper leg $(-2.74 \%)$ and upper hip $(-1.51 \%)$. Since the extract is composed of a mix of bioactive substances, its efficacy may be related to the activity of flavonoids, mainly rutin, that exert a wide range of biochemical, physiological and pharmacological activities. This natural active substance presents several benefits but the most interesting for cellulite treatment is related to its vessel protective activity. Rutin causes changes in microcirculation parameters as a reduction of the synthesis of inflammatory mediators and capillary permeability,
A repetibilidade do sistema de medição é a variação de uma medição retirada das mesmas amostras pelo mesmo técnico. Reprodutibilidade é a variação adicional introduzida quando diferentes técnicos utilizam o sistema de medição para avaliar as mesmas amostras. Por esta razão, este estudo exigiu dois técnicos qualificados e treinados. A proporção de variabilidade devida ao $\mathrm{R}$ $\&$ R é classificada como: $<10 \%$ (excelente); $11-20 \%$ (adequado); $21-30 \%$ (marginal); $\mathrm{E}>30 \%$ (inadequada). A variabilidade total é a soma de dois componentes: a variabilidade do material que está sendo medido e da medição do erro, que é composta pela variabilidade de diferentes técnicos, pela interação do técnico e dos materiais e pelo sistema de medição adequado [20,21]. As avaliações antropométricas são utilizadas devido à sua simplicidade e baixo custo. O método consiste em avaliar os dados de peso, altura, IMC e circunferência corporal. É um sistema quantitativo que pode ser usado como uma maneira indireta de medir a espessura do tecido adiposo. As medidas antropométricas são adequadas para avaliar a obesidade e a adiposidade local, mas não refletem significativamente alterações no quadro da celulite, uma vez que o voluntário pode apresentar perda de peso sem qualquer redução da celulite [22]. Devido à sua característica, é imprescindível que os voluntários sigam corretamente os requisitos do protocolo do estudo.

Como resultado das medidas antropométricas, a aplicação do produto cosmético contendo extratos de Trichilia catigua e Ptychopetalum olacoides proporcionou diferenças estatisticamente significativas antes e após sua aplicação nas seguintes regiões corporais: estômago $(-0,82 \%)$, cintura $(-1,73 \%)$, parte superior da coxa $(-2,53 \%)$, parte superior da perna $(-2,74 \%)$ e quadril superior $(-1,51 \%)$. Uma vez que o extrato é composto por uma mistura de substâncias bioativas, a sua eficácia pode estar relacionada com a atividade dos flavonoides que exercem uma vasta gama de atividades bioquímicas, fisiológicas e farmacológicas, principalmente a rutina. Esta substância ativa natural apresenta vários benefícios, mas o mais interessante para o tratamento da celulite está relacionado com a sua atividade de proteção de vasos. A rutina provoca a modificação dos parâmetros de microcirculação com uma redução da síntese de mediadores inflamatórios e permeabilidade capilar, com diminuição de edema. Além disso, acredita-se que os flavonoides inibem a passagem de proteínas plasmáticas para o interstício, impedindo assim a formação de edemas $[23,24]$.

Quanto à análise de Repetibilidade e Reprodutibilidade (R \& R) [21], a variação foi considerada adequada para a cintura, parte superior da coxa e quadril inferior, significando que os dados originais foram rigorosamente 
with a decrease of edemas. Also, previously published research indicates that flavonoids inhibit the passage of plasmatic proteins to the interstice, thus preventing the formation of edemas [23,24].

Regarding the analysis of Repeatability and Reproducibility (R\&R) [21], the variation was considered adequate for the waist, upper thigh, and lower hip, meaning that the original data had been rigorously achieved. R\&R was marginal for the hip and inadequate for all other regions.

Evaluating the overall measurements and R\&R analysis, it is concluded that the Trichilia catigua and Ptychopetalum olacoides extracts were efficient in reducing circumference in some body areas (regions of the waist, upper thigh, lower hip and upper hip). Nevertheless, it would be necessary to improve and to control this technique in order to adequately standardize the assay in order to minimize deviation and to reduce false positive results, as occurred in some body regions in which R\&R was unsatisfactory.

\section{Conclusions}

The cosmetic formulation containing Trichilia catigua and Ptychopetalum olacoides Bentham hydroglycolic extracts promoted a statically significant reduction of anthropometric measurements in the stomach, waist, upper thigh, upper leg and upper hip areas, and an increase in cutaneous temperature, with no subjects presenting weight loss and reduction on hypodermic thickness. Therefore, the results indicated that the $\mathrm{O} / \mathrm{W}$ emulsion with the extract of Trichilia catigua Adr. Juss (and) Ptychopetalum olacoides Bentham was effective by improving some aspects of the gynoid lipodystrophy, due to reduction of edema and improvement of local microcirculation.

\section{Conflict of Interests}

The authors declare there are no financial and/or personal relationships that could present a potential conflict of interest. alcançados. R \& $\mathrm{R}$ foi marginal para o quadril e inadequado para todas as outras regiões.

Avaliando as medidas gerais e análise de $\mathrm{R} \& \mathrm{R}$, conclui-se que os extratos de Trichilia catigua e Ptychopetalum olacoides foram eficientes na redução de algumas circunferências de áreas corporais (regiões da cintura, coxa, quadril inferior e quadril). No entanto, seria necessário melhorar e controlar esta técnica para padronizar adequadamente o ensaio, a fim de minimizar o desvio e reduzir resultados falso-positivos, como ocorreu em algumas regiões do corpo em que a $\mathrm{R} \& \mathrm{R}$ foi insatisfatória.

\section{Conclusões}

A formulação cosmética contendo extratos hidroglicólicos de Trichilia catigua e Ptychopetalum olacoides Bentham promoveu uma redução estaticamente significativa das medidas antropométricas nas áreas do estômago, cintura, coxa, perna e quadril, aumentando a temperatura cutânea sem que os voluntários apresentassem perda de peso e redução da espessura hipodérmica. Portanto, os resultados indicaram que a emulsão contendo o extrato de Trichilia catigua Adr. Juss (e) Ptychopetalum olacoides Bentham foi eficaz na melhora de alguns aspectos da hidrolipodistrofia ginoide, provavelmente reduzindo o edema e melhorando a microcirculação local.

\section{Conflito de Interesses}

Os autores declaram que não há relações financeiras e / ou pessoais que possam representar um potencial conflito de interesses. 


\section{References/ Referências}

[1] Jackson RF, Roche GC, Shanks SC. A double-blind, placebo-controlled randomized trial evaluating the ability of low-level laser therapy to improve the appearance of cellulite. Lasers Surg Med 2013;45:141-7.

[2] Curri S. Cellulite and fatty tissue microciculation. Cosmet Toilet 1993;108:51-8.

[3] Binazzi M. Cellulite: aspects cliniques et morpho-histologiques. Le J Médecine Esthéthic Chir Dermatologic 1983;10:229-35.

[4] de la Casa Almeida M, Suarez Serrano C, Rebollo Roldán J, Jiménez Rejano JJ. Cellulite's aetiology: a review. J Eur Acad Dermatology Venereol 2013;27:273-8

[5] Santos I, Sarruf F, Balogh T, Pinto C, Kaneko T, Baby A, et al. Hidrolipodistrofia ginoide: aspectos gerais e metodologias de avaliação da eficácia. Arq Bras Ciências Da Saúde 2011;36:85-94.

[6] Goldman A, Gotkin R, Sarnoff D, Prati C, Rossato F. Cellulite: A New Treatment Approach Combining Subdermal Nd: YAG Laser Lipolysis and Autologous Fat Transplantation. Aesthetic Surg J 2008;28:656-62.

[7] Velasco MVR, Tano CTN, Machado-Santelli GM, Consiglieri VO, Kaneko TM, Baby AR. Effects of caffeine and siloxanetriol alginate caffeine, as anticellulite agents, on fatty tissue: histological evaluation. J Cosmet Dermatol 2008;7:23-9.

[8] Hexsel D, Orlandi C, Zechmeister do Prado D. Botanical Extracts Used in the Treatment of Cellulite. Dermatologic Surg 2006;31:866-73.

[9] Arct J, Pytkowska K. Flavonoids as components of biologically active cosmeceuticals. Clin Dermatol 2008;26:347-57.

[10]Farmacopéia dos Estados Unidos do Brasil. 1st ed. São Paulo: Companhia Editora National; 1926.

[11] Beltrame FL, Filho ER, Barros FAP, Cortez DA, Cass QB. A validated higher-performance liquid chromatography method for quantification of cinchonain Ib in bark and phytopharmaceuticals of Trichilia catigua used as Catuaba. J Chromatogr A 2006;1119:257-63.

[12]Rolim A, Maciel C, Kaneko T, Consiglieri V, Salgado-Santos I, Velasco M. Validation assay for total flavonoids, as rutin equivalents, from Trichilia catigua Adr. Juss (Meliaceae) and Ptychopetalum olacoides Bentham (Olacaceae) commercial extract. J AOAC Int 2005;88:1015-9.

[13] Drewes S, George J, Khan F. Recent findings on natural products with erectile-dysfunction activity. Phytochemistry 2003;62:1019-25.

[14] Baby AR, Migliato KF, Maciel CPM, Zague V, Pinto CAS de O, Salgado HRN, et al. Accelerated chemical stability data of O/W fluid emulsions containing the extract of Trichilia catigua Adr. Juss (and) Ptychopetalum olacoides Bentham. Rev Bras Ciências Farm 2007;43:405-12.

[15] Siqueira IR, Lara DR, Silva D, Gaieski FS, Nunes DS, Elisabetsky E. Psychopharmacological Properties of Ptychopetalum Olacoides bentham (Olacaceae). Pharm Biol 1998;36:327-34.

[16] Bielfeldt S, Buttgereit P, Brandt M, Springmann G, Wilhelm K-P. Non-invasive evaluation techniques to quantify the efficacy of cosmetic anti-cellulite products 1. Ski Res Technol 2008;14:336-46.

[17] Agache P. Physiologie de la peau et explorations fonctionnelles cutanées. France: Edition Medicale International; 2000.

[18] Wilczyński S, Koprowski R, Deda A, Janiczek M, Kuleczka N, Błońska-Fajfrowska B. Thermographic mapping of the skin surface in biometric evaluation of cellulite treatment effectiveness. Ski Res Technol 2017;23:61-9.

[19] Katzman M, Cornacchi S, Coonerty-Femiano A, Hughes B, Vermani M, Struzik L, et al. Methyl Nicotinate-Induced Vasodilation in Generalized Social Phobia. Neuropsychopharmacology 2003;28:1846-51.

[20] Antony J, Kaye M. Experimental Quality: A strategic approach to achieve and improve quality. New York: Springer Science \& Business Media; 2012.

[21] Barrentine L. Concepts for R\&R Studies. 2nd ed. Wisconsin: ASQ Quality Press; 2003.

[22] Avram MM. Cellulite: a review of its physiology and treatment. J Cosmet Laser Ther 2004;6:181-5.

[23] Rabe E, Guex J-J, Morrison N, Ramelet A-A, Schuller-Petrovic S, Scuderi A, et al. Treatment of chronic venous disease with flavonoids: recommendations for treatment and further studies. Phlebology 2013.

[24] Goldman M, Hexsel D. Cellulite: Pathophysiology and Treatment. 2nd ed. Boca Raton: CRC Press; 2010. 